\title{
Computer Industry as a National Task
}

\section{The Finnish Computer Project and the Question of State Involvement in the 1970s}

\author{
Petri Paju \\ University of Turku, Department of Cultural History, FI-20014 Turku, Finland \\ petpaju@utu.fi
}

\begin{abstract}
This article studies a forgotten research project of recent Finnish history of information technology by the name of "Suomalainen tietokoneprojekti", in English "The Finnish Computer Project" (FICO). The FICO project was a government-sponsored research project initially aimed at producing a Finnish (mini) computer for international markets, especially in socialist countries. Researchers carried out the project in 1975-1976. However, after the researchers had produced their preliminary study report in six months time, the project was not continued. I argue that historians have misrepresented the FICO project in recent research and when properly studied, the project can offer new perspectives to an early development phase of present-like science and technology policy in Finland. Notwithstanding FICO's topicality, this article focuses on examining what the involved people meant by the "national task" of the project. I further argue that we can best understand FICO as a continuation of earlier ideas on building high technology, in this case electronics and computers, capabilities and expertise as a Finnish national project. Moreover, focusing on these distinct national projections in action might offer one key to understanding similar attempts at "national projects" in other countries as well.
\end{abstract}

Keywords: Computer industry, survey, national project, state-ownership, The Finnish Computer Project, Hans Andersin.

\section{Introduction to a Forgotten Project ${ }^{1}$}

One of the most forgotten, yet also most misrepresented projects of recent Finnish history of information technology has been "Suomalainen tietokoneprojekti" or "SUTI-projekti", in English "The Finnish Computer Project", with an abbreviation FICO project. This paper presents and examines that arguably unsuccessful project from the 1970s Finland for the first time.

Generally, the FICO project is virtually forgotten. However, existing literature references it ambivalently. On the one hand, two data processing history outlines list it in a neutral manner. People who were familiar with the project compiled those outlines [30, 24]. On the other hand, two books by historians offer a much more negative, even

\footnotetext{
${ }^{1}$ I thank Bruce Johnson for valuable comments on the content of this article and on my English.
} 
shadowy image of the FICO. Surprisingly these historians have not studied the project; however, based on other contemporary or later hostile sources, they mention it briefly and deem it potentially harmful to Nokia or the field of computer technology in general and in addition, one of the writers claims the FICO was doomed to failure. This interpretation arises from connecting the FICO with ideas of full-scale state-ownership and even nationalization [19, 23, and even 17], which I think is a mistake.

Surprisingly, none of the above writers has used the public report that the FICO project produced; for an exception, see [22]. I suggest that their detailed report is a valuable source of information not only for studying the project itself but for studying this field in general, for instance as the account reveals some of the researcher's thoughts in this emergent phase of the microcomputer technology [13].

It is well known that history of technology, and history of information technology in particular, tend to be written from the perspective of "winners" [15]. That view runs the risk of making historical knowledge biased in a way that might have serious effects on our understanding about history and subsequent conclusions. Even a while after beginning this study, it was unclear if this mostly forgotten project had resulted in more than the published report of the IT production sector in Finland - it turned out some of its thoughts were actually carried out in successive projects. Moreover, what could make the FICO project relevant today is that it was executed right before from what have been seen as formative years of the later Finnish information technology policy and related research and business decisions. At the end of the 1970s and especially in the early 1980s, with the FICO project fresh in memory, they made important decisions regarding science and technology policy in Finland. I argue the FICO can inform us about this Finnish process of national information technology development from an unusual, 'loser perspective'.

In an international context, the FICO was far from being unique. In fact, the FICO project had taken on many influences from abroad as well as from, at that time, current developments in Finland. Starting in the middle 1960s several governments in both west and east had begun developing national capabilities in computer industry to respond to the "American challenge" by the market leader International Business Machines (IBM) and other U.S.-based companies [16]. Of course, these attempts occurred in Finland too, another country where IBM was a market leader in data processing. From domestic influences to the FICO, we can discuss only its relation to the Social Democratic Party in this article, although we will highlight other avenues of research.

Firstly, this article begins by raising basic questions regarding the FICO project, particularly its project's background and its objectives. The article draws primarily on interviews with some of the people involved, published sources such as the report of the project, and to a lesser extent, archive records. Secondly, this paper studies the meanings attached to the projects' national character, evident already by the naming of the project; see also [18, 27, 28]. Despite all its topical features, I argue that we can best understand the FICO project as a continuation of earlier ideas of a Finnish national project in computers and electronics where national ambitions were first established and tested in the 1950s. By analyzing aspects of this nationally minded project, the paper might offer insight not only for understanding Finnish development but for parallel ones in other Nordic countries such as those related to Regnecentralen, DataSAAB, Norsk Data, and Luxor Ab [see 20, 17]. 


\section{Influence of Economic Pressures and Ongoing Discussions}

As elsewhere in the industrial countries, the computer and the electronics industries in general had been a hot discussion topic for some years in Finland during the late 1960s and early 1970s [see 11, 31, 36, and 23]. Discussions were partly fueled by the fact that since the middle of the 1960s governments in countries such as Britain, France, West Germany, and the Soviet Union had begun developing national capabilities or national champions in computer industry [16]. From 1972 onwards, there was an attempt for a European joint effort, a company named Unidata, which lasted until the end of the year 1975. The Finnish experts knew also of a Danish-Swedish industry plan that however had been abandoned [14].

The contemporary, global, and societal context included the oil crisis and consequent economic depression in Finland too [37, 29], which increased interest toward concurrent advancements in computer technology such as minicomputers, recent microprocessors and their anticipated growing uses in various walks of life. Visions of information networks combined with the future of television added to these expectations [see 33]. In Finland, industrialization had been a central issue that brought many changes following the Second World War. Furthermore, they actively contemplated and planned for new industrial sectors in many groups of industrial, economic, and political nature. In the 1960s, several Finnish companies had entered electronics and were building their expertise with their first products [22].

In society, the 1970s was a decade of heated political activism, debate, and controversy in Finland. Politically, the extreme left was working in a highly visibly manner for a socialist revolution - posing a threat that could be overemphasized by, and for the benefit of, those in politically right-wing parties. In the political turmoil and economic difficulties, governments were rather short-lived. Nevertheless, leading political parties were the Social Democrats and the Centre Party, former agrarians, working in cooperation to build the welfare state. Both had their own industrial political program. The SDP's program strongly favored statist industrial politics that would empower the worker and have his/her voice heard in economic decision making $[35,7]$.

Discussions that eventually lead to the FICO began in 1972, when the Ministry of Finance's co-ordination department, responsible for controlling and guiding data processing in state departments and their installations, appointed a Committee for Computer Policy (or Politics even) (Tietokonepolitiikkakomitea 1972-1974) [30]. This committee forecast an immense growth in computerization. Similar to most industrial countries, the committee wanted to promote domestic production. Among other things, it suggested the state to increase its role as a coordinator in the field, and of computer production too. However, the committee did not make definitions of industrial policy (and politics) [23] in its final report of 1974 but called for further research on the subject [7]. Based on the report of the Committee for Computer Policy, an interim government of non-party ministers appointed both an advisory board (ATK-alan neuvottelukunta) to create a national meeting place for the fast growing field, and some weeks later in November 1975, the interim government established the Finnish Computer Project, with the abbreviation FICO. (Suomalainen tietokoneprojekti or SUTI, in Finnish.) From where did the initiative come? 


\section{The Finnish Computer Project Brings Actors Together}

According to the archive records, it was Hans Andersin who developed the basic ideas for the new project in the spring of 1975 [1]. Andersin was the first professor of data processing technology in Helsinki University of Technology (HUT) since 1970, and acting professor since the chair was established in $1968 .^{2}$ In the spring of 1975 , Professor Andersin gave a presentation where he basically outlined the future project [11]. The conference was "Data Processing Day", an annual meeting organized by a registered association Otadata. Otadata was an association that had been established in the late 1960s by Andersin and his colleagues and students to support and foster data processing expertise by organizing seminars and by funding publications. Interestingly enough, the idea of forming an association to advance the computing field and its domestic knowledge occurred in the Finnish Committee for Mathematical Machines in 1955. Hans Andersin had had his first experiences of the new computing field working for that committee $[27,28]$. By 1975, the Otadata association had extended its social influence by spreading information on electronic data processing in school-TV and other channels [cf. 32; see also 21].

The Data Processing Day also attracted participants from state organizations and companies [9]. Professor Andersin was familiar with the recent Committee for Computer Policy report, and in addition, he had been working on the Committee for Machine Independence in State Data processing that studied how to reduce Finnish dependency on multinational companies [38], such as the market leader IBM. Actually, Andersin had sent his preliminary plan for the new project to the co-ordination department of the Ministry of Finance prior to his presentation at the Data Processing Day $[1,2]$.

In his 1975 talk, Hans Andersin examined the possibilities of Finnish computer industry. To this end, he discussed the history of the field. Surveying past experience, Andersin said that planning Finnish computer industry had not been thought of when the ESKO, the first electronic computer to be constructed in Finland [see 26], was build in the latter half of the 1950s. The audience already knew at that time that he had been involved. Referring to a project that dated back to the 1960 s, he mentioned a Finnish-made Strömberg [Selco] 1000 computer, which became a computer for process control and not a general-purpose computer. In all, he discussed several efforts at building up Finnish computer industry and weighed arguments for and against increased coordination in this sector. In conclusion he suggested a new project "Suomalainen tietokone", in English "A Finnish Computer", be started in some university which would collaborate with other universities and interest groups. Research and development could take place in the universities but a new, strong, and independent company would take responsibility of manufacturing and marketing. This outline was indicative to the later project [11].

Professor Andersin's ideas could not have resonated much better with those in the topical discussions and reports regarding the need to promote domestic production and increase coordination in Finnish computer-related activities. In November 1975, the Helsinki University of Technology and the Ministry of Finance initiated the FICO-project collaboratively. The project was financed by the Ministry of Trade and

\footnotetext{
${ }^{2}$ See also Enlund and Andersin, in this volume.
} 
Industry. The project became known as the Finnish Computer Project. Kauko Pursiainen from the Ministry of Finance headed the FICO management group and Hans Andersin became leader of the project group. They had both worked in the Committee for Machine Independence in State Data Processing [38].

Hans Andersin recalled that the FICO project aimed "at getting the Finnish computer industry to accept one standard computer for everybody's use. I was very much involved in this (in retrospect naive) project." [5]. From the published final report produced by the FICO-team in HUT, we can conclude that the FICO-project was driven by ideas of re-organizing and gathering up information technology (computer-related) industrial and other activities (education, research) under a national objective. They argued this as a necessity to develop effectively this industry sector in Finland [13].

How was this "national project" visible or performed in practice - or did it stay on paper?

The FICO-project seems to have been national first of all so that it involved participants and support from many actors or organizations, both public and private. The management group of the project consisted of state officials (like Pursiainen), researchers (Andersin, Sulonen), and a company representative (from Enso-Gutzeit). The project organized two wide-ranging panels with business and client representatives and visited companies to create discussion and ask comments. The project's discussion meetings were attended by representatives from companies like DatasaabValmet, Digelius Electronics, Nokia Electronics, Outokumpu, Sponsor, Strömberg, Televa, Tietotehdas, TYPLAN, ${ }^{3}$ the state's computer centre VTKK and state-funded research institutions like VTT. (By contrast, the project involved only one university, HUT.) In addition, the project received three expert reports, one of them from IBM Finland (Olli Varho, CEO). They did all this outreach activity to develop a shared understanding of and support for the project's objective of developing this industry sector in Finland in a nationally coherent and efficient way [13]. In other words, in practice the "national project" meant a partly public and to some extent open process and debate. Similar openness and outreaching had already taken place in the project with the ESKO computer in the 1950s [27].

According to interviewees, the FICO was generally well accepted. For example, Nokia welcomed the new project and the idea of cooperation. They wanted to offer their products for other Finnish companies to use. On the other hand, IBM discouraged the project from trying to build a new Finnish production company [5, 7; see also 9].

What was the FICO's relation to politics and especially to the Social Democratic Party? The interviewees agreed that the FICO was not regarded as a political project. The FICO management group was however well aware of the industrial political programs of the Social Democratic Party and the Centre Party. Andersin called the project "inspired" by the ideas of SDP [5, 7, 8, and 9]. It could also be relevant that soon after the FICO was established, a new government began work. Both of the FICO's responsible government departments were taken over by social democratic ministers. Eero Rantala, age 34, became a minister for trade and industry. Early in 1976, they created Valco, a new state-run technology company with strong support by the SDP [31]. The study of Valco Company's possible influence to the FICO is not part of this work.

\footnotetext{
${ }^{3}$ See Enlund and Andersin, in this volume.
} 


\section{Public Report 1976 Revealed Contents: FICO's Thorough Analysis and Discussion}

The FICO research project produced a report of about 85 pages, of which some 70 pages were analysis, followed by 15 pages of proposals. This final report drew on information from the panels organized by the project, company visits in Finland and abroad and several international market forecasting analyses, to scrutinize various activities, including their strengths as well as weaknesses, of the industry in Finland. In all, the report gathered and published information on the field to an extent probably unprecedented.

The report explored different avenues of possible future development. In general, the computer business was to grow rapidly and towards smaller computers, using microprocessors in distributed systems, close to end users. It also mentioned computers at home although mostly the users that were talked about in detail would be situated in offices and companies - presumably, as these were more imminent growth areas [13]. In fact, most of these anticipated developments had already been on the table from early seventies in for example the Otadata association's events and magazine [see 10], but the report offered updated information on the latest market changes and calculated estimates of the future.

In order to promote the Finnish computer industry, the FICO group came up with suggestions to increase coordination and cooperation among the actors of the field. These options were built on products that the group foresaw as promising. The report presented four product areas that the project team considered suitable for a developed Finnish computer industry.

Firstly, microprocessor services would centralize some of the companies' activities at the time. This unit could manufacture microprocessors for Finnish companies to use in their various other products.

Secondly, manufacturing minicomputers (in Finnish pientietokoneet, based or constructed on computers such as Nokia MIKKO 2 or Selco 1000 by Strömberg) developed in Finland or elsewhere and their related appliances.

Thirdly, producing application oriented systems (as for example in health care, teaching and office sectors).

And fourthly, producing software (knowledge management systems and commercial and administrative systems).

Kauko Pursiainen recalled that the focus of the FICO changed in more than one way as it proceeded. Software grew increasingly important during the research process, which began with hardware orientation. In addition, the project leader Hans Andersin seemed to lose his interest in the FICO; however, when asked about it, he denied such a change, Pursiainen continued [7].

By this time, it is most likely that Hans Andersin had learned that other interested parties or groups had their competing views of nationally preferred development in the future Finnish IT industry. Looking back, Andersin wrote, "At that time Nokia claimed to have a computer suitable to be that "standard Finnish computer" and also some other Finnish companies had developed computers that would fit the goal of the project. This resulted in a conflict that made the project work difficult if not impossible to carry out" [5]. For example, the state-owned Televa had built a minicomputer of its own. One could hardly expect coherent and prompt action in this environment, 
which the FICO report also described as somewhat lacking in trust among stakeholders. Nonetheless, the project kept writing for its publication. In addition, in the course of the process the FICO team abandoned its originally central idea of a distinct Finnish computer as a principal goal, in favor of broader ambitions to building up the industry [14].

In all manufacture and marketing, the report stated, the goal needed to be exporting the products, since Finnish markets were too small. Concerning international marketing, the research team noted that Finland was well situated, since the country was on good terms with both the West and East - that is the Comecon or socialist countries. In fact, this position could make the Finnish IT firm an interesting partner to foreign companies [13; see also 34]. Interestingly, and again consistent with the events of the 1950s [27, 28], this national project had adopted a fundamentally international view on future markets. However, seeing commercial potential in the socialist countries was not an unusual vision in Finland at that time. In fact, other Western European national champions had targeted those markets too $[31,16]$.

The FICO report was unusual in not only being thorough but also in making the project's aims, and indirectly its values, explicit in public. The report listed a set of goals and criteria for the future enterprise. These goals included particularly benefiting national economy, increasing preparedness for crises (national security, including military interests, went unmentioned elsewhere) and achieving a "distinctive identity" for this activity and probably its products. The last one did not mean national identity but a Finnish brand name or trademark [13].

Based on these criteria and the product focus, the FICO-project formulated alternatives for supporting the growth and coordination of the field in Finland through existing companies or a new company. Options for a new firm included a company focused on marketing, a company solely devoted to research and development work, and a new full-scale company with its own marketing, R\&D and production. The report stated that in principle, the new full-scale company could be created by strongly supporting the growth of either Nokia or Strömberg among the existing companies. Either of those two was large enough to take on this "major national task" ("kansallinen suurtehtävä"). The state was another option for ownership of the new company. Other ownership options were a small or a large group of state and private companies joining forces [13].

\section{The FICO Publicly Suggests a New Company with Likely State Involvement}

The last chapter of the report elaborated the alternative of a new full-scale company, which was project's suggestion for action. The suggested company would preferably have a broad ownership structure, including the state, and leaving open the possibility of a joint stock company with the state as the majority share holder (as in the case of Valco, 60\% state). Its main activity would be producing application-oriented systems. The suggestion included projections for the first five years of the company. To fulfill the plan it would take 25.6 million Finnish marks (circa 15.8 million EUR (year 2007)) over five years and by that time employ 476 persons (in Helsinki, capital area). According to the plan, the company could start in 1977-1978, but only after more 
detailed planning and research. The report envisioned a relatively low-risk quick start, with a small group of actors, choosing a safe product (preferably something already commissioned), buying an already working company, and using mostly subcontractors in manufacturing [13].

Regardless of which option would be chosen in the future, the project team emphasized that education and research on information technology should be developed and advanced in Finnish universities. Furthermore, the report suggested building a very close relationship between universities and the new company. Those relations were not seen as problematic - a stand (of industry funding endangering the impartiality of research) taken in the Ministry of Education at the time. Here it was a professor, Hans Andersin, who promoted close cooperation between university research and the imagined company. Tellingly of close relations, he had colleagues in University of Tampere who were not included in the FICO process and had they been, they would have been partly influenced by viewpoints inside Nokia with which they cooperated closely in software development [6]. Again, it is worth mentioning that these ideas were not new. In fact both Andersin's interest in applying research in society and his consequent interest in the commercial sphere had surfaced earlier while he was working for the ESKO project in the 1950s [27, 28].

The major issue dividing the parties involved was the role of the state. The FICO report claimed the state had a responsibility in diversifying the production structure of the economy, which would legitimize state actions. According to Eero Rantala, the SDP regarded current technological change as a parallel with the foundation of the state-owned oil company Neste in the late 1940s. In their program, the SDP explicitly invoked economic sovereignty as a national goal $[35,8]$. In the industry, a new company with state-involvement was not desirable - at least not in Nokia. According to Martti Häikiö, political radicalism had created fears among Nokia management of planned nationalization. Lauri Saari, a key figure of Valco Company, wrote that the plans for a state electronics concern appeared in the press and were misreported as paving the way for nationalization [31, 19, see also 3].

Whatever the current beliefs of Nokia and other stakeholders, it is evident that there existed widely different interpretations of what was best for the nation, or of the preferred solutions for a "national project" in this new field. For this particular industry in Finland, a connection to a political party and a clear interest by the SDP was quite new, certainly as compared with the 1950s. However, this does not mean that the SDP was not working for a national mission of its own. Nevertheless, its interest added a party political dimension to the conflicting views among which the FICO sought a unified national project. The FICO had no single solution or preference regarding the state's role in its proposed national project; in these circumstances, it could not have had one. Overall, the parties were far from unanimous in this respect, which we can see as one of the "national questions" of the FICO: coping with conflicting views regarding the state's role.

When assessing the national arguments, qualities and possible impact of the report, one should remember that all this information generated by FICO was publicly available. This is especially important since Martti Häikiö and Ari Manninen in their research seem to indicate that the FICO project was not public but somewhat shadowy and had potentially dangerous objectives (cf. [19, 23]). Significantly in regard to FICO's open and public national interests and wish to contribute socially, Hans 
Andersin and Reijo Sulonen published a detailed article presenting the FICO's work titled "Data Processing Industry Seeks Cooperation" in a respected thrice-monthly economic journal Talouselämä [14, 9; see also 4].

\section{FICO - Continuing in a National Tradition}

Even though the FICO at first looks like a response to current challenges in line with the Committee for Computer Policy (1974) and the co-ordination department of the Ministry of Finance, to acquire deeper understanding of the FICO's national ideas it is necessary to examine the early Finnish history of IT development. After all, Hans Andersin, the FICO's key planner, had been one of the central figures already when electronic computing began in Finland in the 1950s [26].

According to my recent research, a tradition of considering computers from a national perspective had been created in Finland in the 1950s. In fact, this tradition preceded the first operational mainframe computer (from IBM) in Finland, which had been taken into use in a state-owned bank in 1958. Meanwhile in another project commenced in 1954 a computer called ESKO was under construction. Materially the ESKO was based on a German G1a computer from Göttingen [see 26]. Besides developing that machine, a national board of scientists called Matematiikkakonekomitea, the Committee for Mathematical Machines, acted strongly for organizing a nationwide cooperation in a national-minded spirit. Building the ESKO took until 1960, finally resulting in an outdated computer. Nevertheless, the project had, by design, given important stimulus to business also, including the Finnish Cable Factory company that in the mid-1960s became a high-tech part of the Nokia [26-28]. ${ }^{4}$

This early project by patriotic scientists with its national impetus was in no small part executed by the civil engineer Hans Andersin who in 1956, that is simultaneously with his work for the scientist's committee, had also began to work for the IBM in Finland [27, 28]. Since the end of the Committee for Mathematical Machines, Hans Andersin had in the 1960s continued to labor for IBM, followed by a change to the new state's computer centre VTKK (est. 1964), which operated under the coordination department of the Ministry of Finance. These actors (with the possible exception of IBM), I suggest, maintained the tradition of national duties created by the Finnish Committee for Mathematical Machines.

This is because the Committee for Mathematical Machines had, on a self-appointed mission, strived to control and to guide the nascent Finnish computer field. This task of controlling and guiding was taken over by the subsequent State Data processing committee (1960-1961) and officially passed on to the co-ordination department of the Ministry of Finance, although reduced to controlling and guiding data processing in state departments and their installations. The co-ordination department had continued in this (centralized) tradition, when it nominated the Committee for Computer Policy in 1972, mentioned above [27, 30]. Therefore, in addition to being based on the report of the Committee for Computer Policy, the new Finnish Computer Project, FICO, inherited ideas for its national project and its goals from the 1950s both

\footnotetext{
${ }^{4}$ This influence was most evident in the Finnish Committee for Mathematical Machines' attempt to establish a national computing centre in the 1950s. The Finnish Cable Factory company (later Nokia) turned this idea into a business unit [27, 28; Cf. 19].
} 
through its official founder, the co-ordination department of the Ministry of Finance, and through its initiator and project leader Hans Andersin.

\section{Consequences of the Project}

It is worth asking - although probably difficult to answer in detail - what were the possible consequences of the FICO project. Despite the FICO's brief existence, the project had several repercussions. Consequently, another project called KESTI (Keski-Suomen tietojenkäsittelyteollisuus, Data Processing Industry of Central Finland) was established in central Finland. Hans Andersin changed his job (in 1978) to a state-owned company Valmet after he had met Valmet's CEO during the FICO process and discovered that they were seeking new product areas in automation (currently, Valmet's successor company is called Metso). Perhaps more importantly, the FICO and its public report sparked new discussions among the information technology professionals [see 25] who also mobilized the political parties to begin formulating programs regarding this new technology and its social impact. As previously noted, the Otadata association and its Data Processing Day were used to foster discussion $[4,12$, 29; see also [23]. This debate about technology and politics could in turn have had its impact on the prospective Technology Committee (1979-1980) and the many reforms in the early 1980s.

According to economics researcher Raimo Lovio, despite the fact that the state companies in electronics (Valco and Televa) did not continue as independent companies after the late 1970s they acted as generators of new business units. In the 1980s, Lovio continues, the state assumed a new role in developing the industry: no longer an entrepreneur but playing the role of venture capitalist (including funding research) [22]. Rather than generating new business units, the FICO project was a different kind of catalyst, the impact of which is likely to remain blurred. Moreover, studying the FICO - a path not taken - does throw light on ideological underpinnings in technology policy decisions of the early 1980s that today seem value-neutral but in fact, they were highly debated at the time.

On the one hand, then, the FICO's proposals for increasing direct stateinvolvement in the industry failed to draw support at the time. Later, those ideas would be forgotten altogether. One could say it was probably the first and the last (official) effort at establishing a state-owned or state-run company for the computer industry in Finland. Yet this would be too narrow and one-sided an interpretation of the ideas of the project team, since they also made alternative suggestions. These ideas, on the other hand, point to future developments in Finnish information technologies, which actually took place later, such as focusing on supporting the growth of private companies or a company.

When interviewed, Reijo Sulonen, at the time a recent PhD and currently a HUT Professor since the 1980s, contemplated that in retrospect the FICO was most important in providing a forum for discussion among the stakeholders in computer-related production. It is difficult to study these interactions in detail, and to prove direct causal relations to what happened afterwards. Nonetheless, it probably encouraged common understanding, continued exchange, and indirectly, led to actions that outlasted the FICO by years [9]. Re-organisations of the industry and related changes in 
industry and technology politics in the late 1970s and early 1980s tend to confirm this, although the role of the FICO can only be accurately assessed after further research.

\section{Conclusion}

As we have seen, the FICO research project was very much at the cutting edge, sensitive to both technological and political developments in Finland and abroad, particularly the Eastern bloc markets. However, I hope to have shown that even more interesting and revealing than the at that time topical features of the FICO were the continuities it incorporated. In several respects the FICO project built on earlier ideas of what a Finnish national, technological project should be like, since similar features were present in building the ESKO computer and a national computing centre in the 1950s. These features of a national high-tech research-intensive project included wide participation, half-open debate of experts, commercial interests also towards markets abroad, cooperation between the state and private sector and even idealistic national aspirations for unity. Compared with earlier projects and attempts, the FICO was more politically inspired nationally minded endeavor than before although its suggestions probably got most of their political load in the heated debate of the day. FICO's alleged or current inclination to the SDP should not prevent from realizing that the project, along with the SDP, was on a mission to fulfill much older that is nationally deep-rooted and postwar generated ideas of a Finnish high-tech know-how and industry $[27,28]$.

In broad terms, the FICO project exemplifies the complex interaction of culture (especially national aspirations), politics, and technology that shape technological and national developments in all the Nordic countries. Furthermore, focusing on the distinctive national ideas and projections in play might offer one key to understanding similar attempts at "national projects" in other countries as well. It remains to be seen if and what these stories could tell of the Nordic experience of computer industry in general. The FICO further demonstrates that the national ambitions connected to information technology were not abandoned or forgotten in the immediate postwar years or the 1950s, as is the common understanding. Rather, those ideas and practices were molded into the structures and ideologies of the new field. They became axiomatic and they would continue to contribute until at least the 1970s and perhaps beyond. Finally, these national ambitions require further study to acquire deeper understanding about the developments in the computer industry.

\section{References}

\section{Archives}

Government Archives, Prime Minister's Office, Helsinki (Valtioneuvoston arkisto); Ministry of Finance, co-ordination department archives (Valtiovarainministeriö, järjestelyosasto, kansio Hc 60, Suomalainen tietokone.) Since 2008, the Government Archives is part of the National Archives Service (Kansallisarkisto).

[1] Andersin, Hans/TKK: "Suomalainen tietokone.” Aloite valtiovarainministeriön järjestelyosaston atk-jaostolle 15.4.1975. Liite pöytäkirjaan neuvottelusta 14.5.1975 valtiovarainministeriön järjestelyosastolla. Siht. Juhani Pöyhönen. (A Finnish computer. Initiative to the ADP-section of the co-ordination department, the Ministry of Finance, in Finnish) 
[2] Pöytäkirja neuvottelusta 14.5.1975 valtiovarainministeriön järjestelyosastolla. Siht. Juhani Pöyhönen. (Minutes of a meeting in the co-ordination department of the Ministry of Finance, in Finnish) Ministry of Finance, co-ordination department Archives Collections of Kauko Pursiainen

Ministry of Finance, co-ordination department Archives

Collections of Kauko Pursiainen

[3] Presentation handouts concerning Nokia's development, 1975-1980. No author, from c. 1976 (In Finnish) (1976)

Helsinki University of Technology Library, Espoo

Collections of Jouko Seppänen, OtaDATA Newsletters.

Personal Archives of Veikko Jormo

[4] Presentation handout Hans Andersin: "Suomalainen tietokone," (A Finnish computer, in Finnish.) (length five pages) attached to a letter from Hans Andersin to Veikko Jormo, Espoo 26.4.1976. In: Presented with identical name and mentioned (distribution as a handout) in proceedings of Tietojenkäsittelypäivä 1976 (Data Processing Day), Espoo, Otadata ry (1976)

Interviews and correspondence (by the author)

[5] Hans Andersin, communications during 2006 and 2007, incl. discussions and email letters

[6] Reino Kurki-Suonio, email letter 19.10.2007

[7] Kauko Pursiainen, phone interview 24.10.2007

[8] Eero Rantala, email letters 29.10.2007 and 1.11.2007

[9] Reijo (Shosta) Sulonen, interview 26.10.2007

\section{Literature}

[10] Andersin, H.E.: "Anti-data-ideologia". (Anti-data ideology, in Finnish.) (OtaDATA Association's Newsletter) OtaDATA 2/1972, 1

[11] Andersin, H.: Suomalaisen tietokoneteollisuuden mahdollisuudet (Possibilities of Finnish computer industry, in Finnish). In: Proceedings of Tietojenkäsittelypäivä 1975 (Data Processing Day). Espoo, Otadata ry (1975)

[12] Andersin, H.: "ATK - haaste puolueille" (ADP - a Challenge for political parties, in Finnish). In: Proceedings of Tietojenkäsittelypäivä 1977 (Data Processing Day). Espoo, Otadata ry (1977)

[13] Andersin, H.E., Parkkinen, M., Sulonen, R.: Esitutkimus suomalaisen tietojenkäsittelyteollisuuden kehittämismahdollisuuksista. (Preliminary study of development possibilities in Finnish data processing industry, in Finnish) Helsinki University of Technology, Information Processing Laboratory, Sarja A, 7/76. Espoo (1976)

[14] Andersin, H., Sulonen, R.: Tietojenkäsittelyteollisuus tavoittelee yhteistyötä (Data Processing Industry Seeks Cooperation, in Finnish) Talouselämä 17/1976 39, 20-22, 57-58 (1976)

[15] Bijker, W.: Of Bicycles, Bakelites and Bulbs - Towards a theory of sosiotechnical change. The MIT Press, London (1995)

[16] Coopey, R.: Information Technology Policy: Competing for the Future. In: Coopey, R. (ed.) Information Technology Policy. An International History, pp. 1-23. Oxford University Press, New York (2004) 
[17] Gram, C., Laaksonen, T., Ohlin, T., Lawson, H (Bud.), Skår, R., Stangegaard, O.: History of the Nordic computer industry. In: Bubenko Jr., J., Impagliazzo, J., Sølvberg, A. (eds.) History of Nordic Computing. IFIP WG9.7 First Working Conference on the History of Nordic Computing (HiNC1), Trondheim, Norway, June 16-18, 2003, pp. 179-190. Springer, New York (2005)

[18] Hecht, G.: The Radiance of France. In: Nuclear Power and National Identity after World War II. MIT Press, Cambridge (1998)

[19] Häikiö, M.: Nokia Oyj:n historia. 1. Fuusio. Yhdistymisten kautta suomalaiseksi monialayritykseksi 1865-1982 (History of the Nokia Corporation, part I, in Finnish) Helsinki (2001)

[20] Johansson, M.: Smart, Fast and Beautiful. On Rhetoric of Technology and Computing Discourse in Sweden 1955-1995. CD-ROM. Thesis for the Ph.D. degree. Linköping Studies in Arts and Science 164. Linköping University, Linköping (1997)

[21] Jotuni, P.: Teknillisessä korkeakoulussa atk 'läpäisee' kaikki oppiaineet (ADP permeates through all subjects in Helsinki University of Technology, in Finnish) IBM-katsaus 4/1991, 10-17 (1991)

[22] Lovio, R.: Evolution of Firm Communities in New Industries - The Case of the Finnish Electronics Industry. Acta Universitatis Oeconomicae Helsingiensis Series A:92. The Helsinki School of Economics and Business Administration, Helsinki (1993)

[23] Manninen, A.T.: Näin tehtiin Suomesta tietoyhteiskunta (How Finland was made into an information society, in Finnish). Helsinki, Talentum (2003)

[24] Nevalainen, R.: Suomi tietoyhteiskunnaksi - eespäin tiedon poluilla ja valtateillä. Tietoyhteiskuntatoiminnan lyhyt historia (Finland into an information society - forwards on the paths and roads of information. A Short history of information society activities, in Finnish) SITRA, Helsinki (1999)

[25] Otala, M.: "Suomalainen ja tietokone," (A Finn and the Computer, in Finnish). In: Proceedings of Tietojenkäsittelypäivä 1977 (Data Processing Day). Espoo, Otadata ry (1977)

[26] Paju, P.: A Failure Revisited: The First Finnish Computer Construction Project. The Establishing of a National Computing Center in Finland. In: Bubenko Jr., J., Impagliazzo, J., Sølvberg, A. (eds.) History of Nordic Computing. IFIP WG9.7 First Working Conference on the History of Nordic Computing (HiNC1), Trondheim, Norway, June 16-18, 2003, pp. 79-94. Springer, New York (2005)

[27] Paju, P.: "Ilmarisen Suomi” ja sen tekijät. Matematiikkakonekomitea ja tietokoneen rakentaminen kansallisena kysymyksenä 1950-luvulla. Doctoral dissertation with English Summary (The Finnish Committee for Mathematical Machines and computer construction as a national project in the 1950s, in Finnish.) University of Turku publications C 269, Turku (2008)

[28] Paju, P.: National Projects and International Users: Finland and Early European computerization. IEEE Annals of the History of Computing 30, 77-91 (2008)

[29] Proceedings of Tietojenkäsittelypäivä 1977 (Data Processing Day, in Finnish). Espoo, Otadata ry (1977)

[30] Pursiainen, K.: "Valtionhallinnon tietojenkäsittelyn alkuvaiheita." (Early Phases of Data Processing in State Administration, in Finnish). In: Tienari, M. (ed.) Tietotekniikan alkuvuodet Suomessa (The First Years of Information Technology in Finland, in Finnish), Suomen Atk-kustannus Oy, Jyväskylä, pp. 205-242 (1993)

[31] Saari, L.: Valcoinen kirja (A book on Valco, in Finnish). Tammi, Helsinki (1981)

[32] Saarikoski, P.: Koneen lumo. Mikrotietokoneharrastus Suomessa 1970-luvulta 1990luvun puoliväliin (The Lure of the Machine. The Personal Computer Interest in Finland from the 1970s to the mid-1990s, in Finnish) Nykykulttuurin tutkimuskeskuksen julkaisuja 83. Jyväskylä (2004) 
[33] Salmi, H.: Televisio, tietokone ja tietämisen politiikka. Tietämisen teknologiat vuoden 1975 tv-dokumentissa Maailmantelevisio (Television, computer and the politics of information. Information technologies in a 1975 TV documentary World Vision, in Finnish). In: Salmi, H., Paju, P., Parikka, J., Saarikoski, P. (eds.) Tanja Sihvonen ja Jaakko Suominen: Välimuistiin kirjoitetut. Lukuja Suomen tietoteknistymisen kulttuurihistoriaan (Written in the Cache. Contributions to the cultural history of Finnish computerization, in Finnish) k \& h. Turku, pp. 55-79 (2006)

[34] Seppänen, J.: SEV-yhteistyön mahdollisuudet suomalaiselle tietokoneteollisuudelle. In: Proceedings of Tietojenkäsittelypäivä 1976 (Data Processing Day). (Comeconcooperation possibilities for Finnish computer industry, in Finnish). Espoo, Otadata ry (1976)

[35] SDP: n teollisuuspoliittinen ohjelma. Hyväksytty SDP:n puoluekokouksessa Jyväskylässä 5.-8.6.1975. (Social Democratic Party's program for industrial policy 1975, in Finnish) (1975)

[36] Suominen, J.: Koneen kokemus. Tietoteknistyvä kulttuuri modernisoituvassa Suomessa 1920-luvulta 1970-luvulle. (Experiences with machines. Computerised culture in the process of Finnish Modernisation from the 1920s to the 1970s, in Finnish). Vastapaino, Tampere (2003)

[37] Wallenius, J.: Irti lamasta - tietokoneet tuottamaan (Breaking free from the recession computers to increase production, in Finnish). In: Proceedings of Tietojenkäsittelypäivä 1976 (Data Processing Day), Espoo, Otadata ry (1976)

[38] Valtion Atk:n koneriippumattomuustoimikunnan mietintö. Komiteanmietintö 1973: 116. Helsinki 1973. (Report of the Committee for Machine Independence in State Data Processing, in Finnish) (1973) 